\title{
PENGARUH KOMBINASI PERLAKUAN KALIUM HIDROKSIDA DAN NATRIUM KARBONAT DALAM EKSTRAKSI NATRIUM ALGINAT TERHADAP KUALITAS PRODUK YANG DIHASILKAN
}

\author{
Jamal Basmal", Thamrin Wikanta") dan Tazwir")
}

\begin{abstract}
ABSTRAK
Penelitian ekstraksi sodium alginat ( $\mathrm{Na}$-alginat) telah dilakukan menggunakan rumput laut coklat Sargassum filipendula yang direndam di dalam larutan $\mathrm{KOH}: 0,25 \%, 0,50 \%, 0,75 \%$, dan $1,0 \%$ dengan waktu perendaman setiap perlakuan 30 dan 60 menit. Selanjutnya rumput laut diekstrak dengan perlakuan konsentrasi natrium karbonat $\left(\mathrm{Na}_{2} \mathrm{CO}_{3}\right)=0,75 \%, 1,50 \%$ dan $2,25 \%$. Hasil penelitian menunjukkan bahwa konsentrasi larutan $\mathrm{KOH}$ tidak berpengaruh terhadap rendemen $\mathrm{Na}$-alginat yang dihasilkan, tetapi berpengaruh nyata terhadap tingkat kekentalan, derajat putih, dan kadar susut pengeringan (CAW = clean anhydrous seaweed). Sedangkan lama waktu perendaman rumput laut memberikan pengaruh nyata terhadap rendemen, tingkat kekentalan, derajat putih dan kadar susut pengeringan Na-alginat. Nilai terbaik ditemukan pada perlakuan rumput laut coklat Sargassum filipendula yang diperlakukan dengan larutan $\mathrm{KOH} 0,50 \%$, direndam selama 60 menit dan kemudian diekstrak dengan larutan $\mathrm{Na}_{2} \mathrm{CO}_{3} 1,50 \%$. Pada perlakuan terbaik tersebut diperoleh nilai rendemen sebesar $6,8 \%$, tingkat kekentalan $=272,6 \mathrm{cps}$, derajat putih $=54,8 \%$, dan kadar susut pengeringan $=19,6 \%$.
\end{abstract}

\section{ABSTRACT: Combined Effect of Potassium Hydroxide and Sodium Carbonate Treatments in the Extraction of Sodium Alginate on the quality of its Product. By: Jamal Basmal, Thamrin Wikanta and Tazwir}

Experiment on sodium alginate (Na-alginate) extraction was carried out using brown seaweed (Sargassum filipendula). The brown seawed were soaked in the potassium hydroxide $(\mathrm{KOH})$ solution with concentrations of $0.25 \%, 0.50 \%, 0.75 \%$ and $1.0 \%$ for 30 and 60 minutes, followed by extraction using different concentrations of sodium carbonate $10.75 \%$, $1.50 \%$ and $2.25 \%$ ). The results indicated that potassium hydroxide treatment showed insignificant effect on the yield of $\mathrm{Na}$-alginate but gave significant effect on the viscosity, degree of whiteness, and clean anhydrous seaweed (CAW). Soaking time indicated a significant effect on viscosity, degree of whiteness, and CAW. The brown seaweeds that had been treated with $0.50 \% \mathrm{KOH}$ for 60 minutes followed by extraction using $1.50 \% \mathrm{Na}_{2} \mathrm{CO}_{3}$ was found to be the best product. The viscosity, yield, degree of whiteness and CAW were 272,6 cps, $6.8 \%, 54.8 \%, 19.6 \%$ respectively.

KEYWORDS: brown seaweed, potassium hydroxide (KOH), sodium carbonate $\left(\mathrm{Na}_{2} \mathrm{CO}_{3}\right), \mathrm{Na}$-alginate

\section{PENDAHULUAN}

Alginat adalah salah satu jenis polisakarida yang terkandung di dalam thallus rumput laut, khususnya rumput laut coklat Phaeophycea dari kelompok Marcocystis, Laminnaria, Aschophyllum, Nerocystis, Ecklonia, Fucus, Lessonia, Burnvillaea, Turbinaria dan Sargassum (McHugh, 1987). Sedangkan jenis rumput laut coklat yang banyak terdapat di perairan Indonesia adalah dari kelompok Turbinaria $s p$ dan Sargassum $s p$. Kandungan alginat dari rumput laut coklat sangat bervariasi tergantung dari tingkat kesuburan perairan, musim, bagian dari tanaman yang diekstrak dan jenis rumput laut (King, 1983). Pada saat musim, kelompok rumput laut coklat genus Sargassum cukup melimpah dan oleh nelayan rumput laut coklat tersebut dipanen untuk dikeringkan selama 2-3 hari di

') Peneliti pada Pusat Riset Pengolahan Produk dan Sosial Ekonomi Kelautan dan Perikanan 
bawah sinar matahari yang kemudian disimpan dalam waktu yang relatif lama. Teknik penanganan seperti ini dapat merusak kualitas rumput laut selama penyimpanan karena rumput laut coklat yang telah dikeringkan masih banyak mengandung garam. Kristal garam yang terdapat di permukaan bahan bersifat higroskopis sehingga dapat meningkatkan kelembaban rumput laut selama penyimpanan. Perubahan kadar air di permukaan rumput laut akan mengakibatkan penurunan kualitas rumput laut karena terjadinya dekomposisi oleh bakteri atau kapang. Untuk mencegah terjadinya dekomposisi rumput laut selama penyimpanan maka faktor penanganan awal sangat berpengaruh. Cara penanganan yang dimaksud adalah teknik pengawetan yang diberikan sebelum rumput laut coklat dikeringkan.

Istini dan Zatnika, (1991); Basmal et al, (1998a \& b), Yani, (1988) telah mencoba memperbaiki teknik penanganan bahan baku rumput laut penghasil karagenan menggunakan larutan alkali $(\mathrm{KOH})$ dan dari hasil penelitian ternyata dapat memperbaiki kualitas karagenan yang dihasilkan. Fungsi dari larutan alkali adalah untuk menarik protein dan bahan lain seperti mineral ( $\mathrm{NaCl}$, Kalium dan Yodium) di samping itu, larutan alkali dengan adanya ion $\mathrm{K}^{+}$akan membentuk kappa-carageenan dari $\mu$-carageenan. Karagenan dan alginat merupakan polisakarida yang mempunyai struktur linier yang sama yakni mempunyai gula kopolimer (copolymerized sugar) tidak lebih dari dua, tingkat kekentalan tinggi, larutan tidak stabil dan sukar larut. Usaha untuk mempertahankan kandungan alginat di dalam thallus rumput laut coklat dapat dilakukan dengan memberikan pra-perlakuan setelah rumput laut dipanen. Basmal et al, (1998b) menemukan bahwa pemberian perlakuan alkali encer pada rumput laut coklat (Turbinaria ornata) setelah panen dapat meningkatkan nilai kekentalan dan rendemen sodium alginat yang dihasilkan. Sedangkan $\mathrm{Na}_{2} \mathrm{CO}_{3}$ berfungsi mengekstrak kandungan alginat yang terdapat di dalam thallus rumput laut coklat. Kecepatan reaksi alginat yang ada di dalam thallus sangat tergantung pada konsentrasi, suhu dan lama waktu ekstraksi yang diberikan.

Tujuan dari penelitian ini adalah untuk mencari konsentrasi kalium hidroksida terbaik terhadap kualitas $\mathrm{Na}$-alginat yang dihasilkan.

\section{BAHAN DAN METODE}

\section{Bahan}

Dalam penelitian ini digunakan rumput laut coklat dari genus Sargassum filipendula yang diperoleh dari Binuangeun, Jawa Barat. Rumput laut tersebut dikeringkan alami dengan matahari selama 2 hari, kemudian dibawa ke Pusat Riset Pengolahan Produk dan Sosial Ekonomi Kelautan dan Perikanan Jakarta untuk diproses lebih lanjut. Adapun bahan pembantu yang digunakan adalah larutan $\mathrm{KOH}$ yang berfungsi untuk menarik mineral $(\mathrm{NaCl})$, protein, dan zat warna dari thallus rumput laut coklat serta untuk mengikat alginat agar tidak terjadi penurunan kandungan alginat (leaching-out) selama proses penanganan setelah panen. Larutan $\mathrm{HCl}$ digunakan untuk membentuk asam alginat sedangkan $\mathrm{Na}_{2} \mathrm{CO}_{3}$ teknis untuk mengekstrak alginat dari thallus rumput laut coklat. Larutan $\mathrm{NaOH}$ berfungsi membentuk sodium alginat dari asam alginat, sedangkan celite digunakan sebagai filter aid untuk pemurnian alginat.

\section{Metode}

Rumput laut coklat kering dicuci dengan air bersih untuk selanjutnya diperlakukan menggunakan empat taraf konsentrasi larutan alkali $(\mathrm{KOH})$ encer yakni larutan $\mathrm{KOH} \quad 0,25 \%$ (a1); 0,50\% (a2); 0,75\% (a3); dan 1,0\% (a4) dengan lama waktu perendaman masingmasing perlakuan adalah 30 menit (b1) dan 60 menit (b2). Rumput laut yang telah diperlakukan tersebut dikeringkan hingga kadar air $30 \%$ bb (bobot basah). Perlakuan selanjutnya adalah ekstraksi rumput laut kering menggunakan tiga taraf konsentrasi $\mathrm{Na}_{2} \mathrm{CO}_{3}$ yakni $0,75 \%$ (c1); $1,50 \%$ (c2) dan $2,25 \%$ (c3). Metoda ekstraksi yang digunakan adalah metoda yang telah dikembangkan oleh Instalasi Penelitian Perikanan Laut Slipi (Anonimus, 2000),yaitu: proses demineralisasi, pencucian, ekstraksi, penarikan asam alginat menggunakan larutan $\mathrm{HCl}$, pencucian, pertukaran ion $\mathrm{H}^{+}$dengan ion $\mathrm{Na}^{+}$dari larutan $\mathrm{NaOH}$ kemudian penarikan sodium alginat menggunakan alkohol dan pengeringan. Pada penelitian ini suhu ekstraksi ditetapkan $60^{\circ} \mathrm{C}$ dengan lama waktu ekstraksi 60 menit untuk setiap perlakuan yang diberikan. Untuk mendapatkan hasil yang lebih akurat maka penelitian ini dirancang menggunakan rancangan acak lengkap dengan dua kali 
ulangan (Sudjana, 1988), sedangkan untuk melihat interaksi setiap faktor perlakuan digunakan uji perbandingan wilayah Duncan (Walpole, 1995). Parameter yang dianalisis untuk menentukan perlakuan alkali yang terbaik adalah rendemen, kekentalan ( $1 \%$ larutan $\mathrm{Na}$-alginat; $25^{\circ} \mathrm{C}$ ) (Cottrel dan Kovack, 1980), kadar susut pengeringan dan derajat putih menggunakan alat Color Difference Meter model DICOM ND 504 DE.

\section{HASIL DAN PEMBAHASAN}

\section{Rendemen}

Nilai rata-rata rendemen natrium alginat rumput laut Sargassum filipendula yang masing-masing mendapatkan perlakuan perendaman dalam larutan $\mathrm{KOH}(0,25 \%$; $0,50 \% ; 0,75 \%$ dan $1,0 \%)$ dengan waktu perendaman untuk setiap perlakuan 30 dan 60 menit, diikuti ekstraksi menggunakan larutan $\mathrm{Na}_{2} \mathrm{CO}_{3}(0,75 \% ; 1,50 \%$ dan $2,25 \%)$ adalah berkisar antara $0,84 \%-12,8 \%$. Nilai tertinggi diperoleh dari natrium alginat dengan kombinasi perlakuan perendaman dalam larutan $\mathrm{KOH} 1,0 \%$ selama 30 menit dan diekstrak dengan larutan $\mathrm{Na}_{2} \mathrm{CO}_{3} \quad 1,5 \%$. Sedangkan nilai terendah diperoleh dari natrium alginat dengan kombinasi perlakuan perendaman dalam larutan $\mathrm{KOH} \quad 0,25 \%$ selama $\mathbf{3 0}$ menit dan diekstrak dengan larutan $\mathrm{Na}_{2} \mathrm{CO}_{3} 1,5 \%$. Secara umum nilai rendemen yang diperoleh untuk semua perlakuan termasuk rendah. Hal ini kemungkinan dipengaruhi oleh tingkat kekentalan filtrat, jumlah celite sebagai filter aid yang diberikan, dan suhu penyaringan serta metoda penyaringan yang menggunakan mesin vakum berkekuatan 0,25 pK. Pada Gambar 1 dapat dilihat nilai rendemen sodium alginat yang dihasilkan masing-masing perlakuan.

Hasil analisis ragam dengan selang kepercayaan $95 \%$ menunjukkan bahwa variasi konsentrasi larutan $\mathrm{KOH}(0,25 \%$, $0,50 \%, 0,75 \%$ dan $1,0 \%$ ) tidak berpengaruh nyata terhadap rendemen. Waktu perendaman 30 menit dan 60 menit serta variasi konsentrasi $\mathrm{Na}_{2} \mathrm{CO}_{3}$ sebagai bahan pengekstrak alginat masing-masing berpengaruh nyata terhadap rendemen. Sedangkan interaksi antara konsentrasi larutan $\mathrm{KOH}$ dengan waktu perendaman menunjukkan pengaruh yang nyata terhadap rendemen. Ion $\mathrm{K}^{+}$dari larutan $\mathrm{KOH}$ mengakibatkan alginat menjadi kalium alginat (Chapman and Chapman 1980), di samping itu dengan adanya pemberian perlakuan alkali telah menyebabkan kulit luar thallus yang berwarna coklat terpisah (Basmal, 2002). Diduga ini merupakan salah satu faktor rendahnya rendemen yang dihasilkan pada perlakuan ini. Selain itu mungkin disebabkan pula rumput laut yang diperoleh dari alam masih terlalu muda.

Hasil uji perbandingan wilayah berganda Duncan menunjukkan bahwa lama perendaman 30 dan 60 menit memberikan nilai yang berpengaruh nyata terhadap rendemen. Sedangkan bahan kimia pengekstrak, yakni larutan $\mathrm{Na}_{2} \mathrm{CO}_{3} \quad 1,50 \%$ memberikan pengaruh nyata pada konsentrasi $0,75 \%$, dan $2,25 \%$. Peningkatan

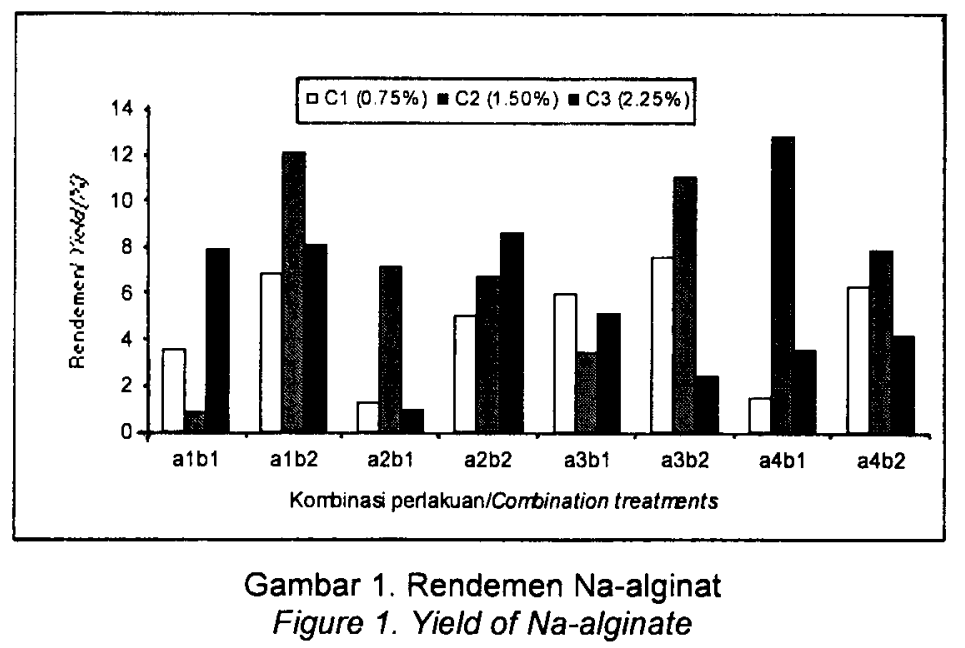

$\mathrm{a} 1=\mathrm{KOH} 0,25 \% ; \mathrm{a} 2=\mathrm{KOH} 0,50 \% ; \mathrm{a} 3=\mathrm{KOH} 0,75 \% ; \mathrm{a} 4=\mathrm{KOH} 1,0 \% ; \mathrm{b} 1=$ waktu perendaman/soaking time $=30$ menit $(\mathrm{min}) ; \mathrm{b} 2=$ waktu perendaman/soaking time $=60$ menit $(\min ) ; \mathrm{c} 1=\mathrm{Na}_{2} \mathrm{CO}_{3} 0,75 \% ; \mathrm{c} 2=$ $\mathrm{Na}_{2} \mathrm{CO}_{3} 1,50 \% ; \mathrm{c} 3=\mathrm{Na}_{2} \mathrm{CO}_{3} 2,25 \%$. 
konsentrasi $\mathrm{KOH}$ dengan lama perendaman rumput laut 30 menit cenderung meningkatkan nilai rendemen. Hal ini diduga proses ekstraksi berjalan lebih sempurna dibandingkan dengan perlakuan lain. Penggunaan $\mathrm{KOH}$ pada perlakuan ini bertujuan untuk membuka permukaan dinding sel rumput laut sehingga permukaannya lebih luas dan lebih mudah untuk melepaskan alginat (Basmal, et al., 1998 ${ }^{\mathrm{b}}$ ). Untuk rumput laut yang direndam selama 60 menit, dengan peningkatan konsentrasi larutan $\mathrm{KOH}$ cenderung menurunkan rendemen.

Penggunaan konsentrasi $\mathrm{KOH}$ yang terlalu tinggi dalam waktu yang relatif cukup lama telah menyebabkan sebagian alginat di dalam sel rumput laut ikut bereaksi dengan larutan $\mathrm{KOH}$ dan tertarik keluar dari jaringan sel rumput laut. Hal ini terlihat dari larutan sisa perendaman yang semakin kental. Menurut Percival (1970), asam alginat akan terdegradasi oleh enzim, alkali atau senyawa pereduksi. Bila alginat terdegradasi oleh larutan alkali akan terbentuk sejumlah turunan asam uronat tidak jenuh. Hasil analisis ragam dengan tingkat kepercayaan $95 \%$ menunjukkan adanya interaksi masing-masing perlakuan yakni: antara perlakuan perendaman dalam . larutan $\mathrm{KOH}$ dengan konsentrasi $\mathrm{Na}_{2} \mathrm{CO}_{3}$ dan antara perlakuan perendaman dalam larutan $\mathrm{KOH}$ dengan waktu perendaman. Perlakuan konsentrasi $\mathrm{Na}_{2} \mathrm{CO}_{3}$ sebagai bahan pengekstrak alginat dari dalam rumput laut tidak menunjukkan perbedaan yang nyata terhadap rendemen $\mathrm{Na-alginat} \mathrm{yang} \mathrm{dihasilkan.} \mathrm{Pada} \mathrm{konsentrasi}$ larutan $\mathrm{Na}_{2} \mathrm{CO}_{3} \quad 2,25 \%$ menghasilkan nilai rendemen yang semakin menurun dengan semakin meningkatnya konsentrasi larutan $\mathrm{KOH}$ (Gambar 1). Hal ini diduga kelebihan $\mathrm{KOH}$ di dalam rumput laut telah menyebabkan terjadinya suasana yang terlalu basa yang menyebabkan terhidrolisisnya sebagian alginat di dalam rumput laut sehingga pada saat direaksikan dengan asam $(\mathrm{HCl})$ jumlah asam alginat yang diperoleh sedikit. Suasana yang terlalu basa dapat mendegradasi alginat dengan memotong rantai polimer menjadi oligosakarida dan terdegradasi lebih lanjut menjadi asam 4-deoksi-5-ketouronat. Yani (1988) menyatakan bahwa pada konsentrasi $\mathrm{Na}_{2} \mathrm{CO}_{3}$ lebih dari $2 \%$ rendemen cenderung menurun.

\section{Kekentalan}

Nilai rata-rata kekentalan natrium alginat yang diperoleh berkisar antara 3,9 cp sampai 272,55 cps. McHugh (1987) menyatakan bahwa nilai kekentalan alginat sangat dipengaruhi oleh beberapa faktor seperti berat molekul, konsentrasi larutan $\mathrm{Na}_{2} \mathrm{CO}_{3}$, suhu, $\mathrm{pH}$ dan kelebihan garam $\mathrm{NaCl}$ pada alginat yang telah diekstrak. Nilai kekentalan tertinggi diperoleh pada perlakuan larutan $\mathrm{KOH} 0,50 \%$ dengan lama perendaman 60 menit dan diekstrak dengan larutan $\mathrm{Na}_{2} \mathrm{CO}_{3} \quad 1,50 \%$. Sedangkan nilai kekentalan terendah diperoleh pada perlakuan larutan $\mathrm{KOH} 0,25 \%$ dengan lama perendaman 30 menit dan diekstrak dengan larutan $\mathrm{Na}_{2} \mathrm{CO}_{3} \quad 2,25 \%$ (Gambar 2). Winarno (1990) menyatakan bahwa nilai kekentalan alginat $(1 \%$ larutan

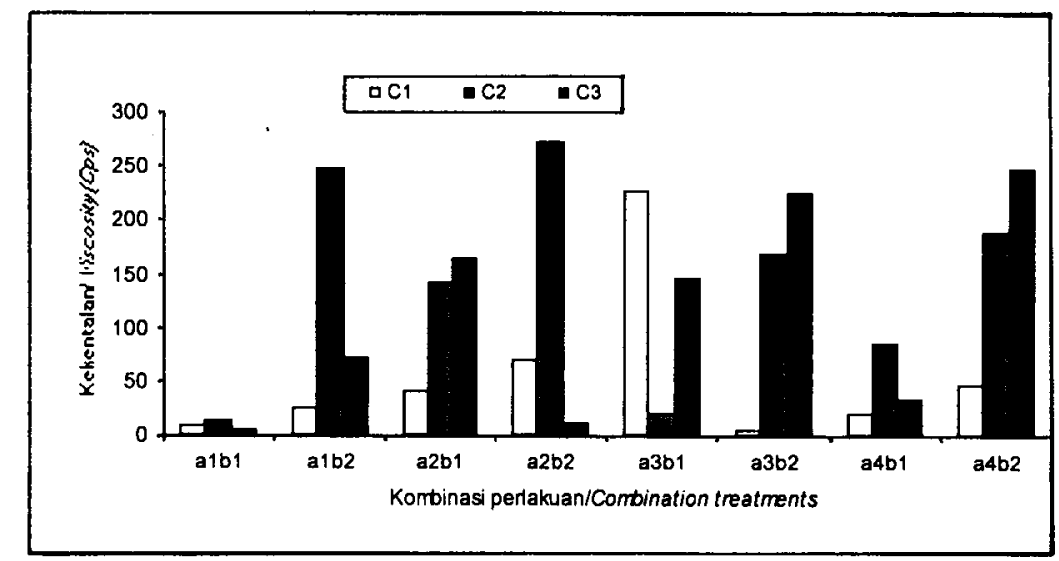

Gambar 2. Nilai kekentalan Na-alginat setelah mendapatkan perlakuan Figure 2. Viscosity value of Na-alginate after treatments

a1 $=\mathrm{KOH} 0,25 \% ; \mathrm{a} 2=\mathrm{KOH} 0,50 \% ; \mathrm{a} 3=\mathrm{KOH}$ 0,75\%; a4=KOH 1,0\%; b1=waktu perendaman/soaking time $=30$ menit $(\mathrm{min}) ;$ b2 $=$ waktu perendaman/soaking time $=60$ menit $(\mathrm{min}) ; \mathrm{c} 1=\mathrm{Na}_{2} \mathrm{CO}_{3} 0.75 \% ; c 2=\mathrm{Na}_{2} \mathrm{CO}_{3}$ $1,50 \% ; \mathrm{c} 3=\mathrm{Na}_{2} \mathrm{CO}_{3} 2,25 \%$. 
alginat; $25^{\circ} \mathrm{C}$ ) berkisar antara 10 sampai 5000 cps. Hasil analisis ragam terhadap nilai kekentalan menunjukkan bahwa masingmasing perlakuan perendaman dalam larutan $\mathrm{KOH}$, lama waktu perendaman dan konsentrasi $\mathrm{Na}_{2} \mathrm{CO}_{3}$ serta interaksi antara perlakuan perendaman dalam larutan $\mathrm{KOH}$ dengan lama waktu perendaman berpengaruh nyata pada tingkat kepercayaan $95 \%$. Hasil uji wilayah berganda Duncan menunjukkan bahwa antara perlakuan perendaman dalam larutan $\mathrm{KOH} \quad 0,75 \%, 0,50 \%$, dan $1,0 \%$ tidak berpengaruh nyata, tetapi berpengaruh nyata ternadap larutan $\mathrm{KOH} 0,25 \%$. Sedangkan perlakuan larutan $\mathrm{Na}_{2} \mathrm{CO}_{3}(1,50 \% ; 2,25 \%$ dan $0,75 \%$ ) sebagai bahan pengekstraksi menunjukkan perbedaan yang nyata terhadap kekentalan $\mathrm{Na}$-alginat.

Peningkatan konsentrasi $\mathrm{KOH}$ pada lama perendaman 60 menit telah meningkatkan nilai kekentalan. Keadaan ini diduga karena peningkatan konsentrasi larutan $\mathrm{KOH}$ telah menyebabkan alginat yang mempunyai bobot molekul lebih kecil mudah tertarik dari dinding sel rumput laut, sedangkan alginat yang mempunyai bobot molekul lebih tinggi tidak ikut tertarik dari dinding sel rumput laut, sehingga pada perubahan asam alginat menggunakan larutan $\mathrm{NaOH} 5 \%$ menghasilkan $\mathrm{Na}$-alginat yang mempunyai bobot molekul tinggi. McHugh (1987) menyatakan bahwa semakin tinggi bobot molekul dan konsentrasi alginat maka nilai kekentalan akan semakin tinggi.

Peningkatan konsentrasi $\mathrm{Na}_{2} \mathrm{CO}_{3}$ lebih besar dari $1,50 \%$ yang diikuti dengan peningkatan konsetrasi larutan $\mathrm{KOH}$ akan menurunkan nilai kekentalan. Hasil uji statistik menunjukkan bahwa perendaman rumput laut segar selama 60 menit pada larutan $\mathrm{KOH}$ $1,0 \%$ dapat meningkatkan nilai kekentalan. Pemberian $\mathrm{Na}_{2} \mathrm{CO}_{3}$ sebagai pengekstraksi akan meningkatkan jumlah garam yang terbentuk. Garam yang mungkin terbentuk akibat kelebihan ion $\mathrm{Na}^{+}$yang bereaksi pada saat pembentukan asam alginat menggunakan larutan $\mathrm{HCl} 10 \%$ adalah garam $\mathrm{NaCl}$. Menurut Cottrel dan Kovacs (1980) serta King (1983) keberadaan garam monovalen hingga $0,5 \%$ dapat mempengaruhi penurunan nilai kekentalan $\mathrm{Na}$-alginat. $\mathrm{Na}$-alginat yang dihasilkan pada penelitian ini termasuk alginat yang mempunyai nilai kekentalan rendah.

\section{Derajat putih}

Nilai rata-rata derajat putih natrium alginat yang dihasilkan berkisar antara $31,2 \%-79,4 \%$. Nilai tertinggi diperoleh pada perlakuan kombinasi perendaman dalam larutan $\mathrm{KOH}$ $0,75 \%$ yang direndam selama 60 menit dan diekstrak dengan larutan $\mathrm{Na}_{2} \mathrm{CO}_{3} 2,25 \%$. Nilai terendah derajat putih diperoleh pada perlakuan kombinasi perendaman dalam larutan $\mathrm{KOH} 1,0 \%$ yang direndam selama 60 menit dan diekstrak dengan larutan $\mathrm{Na}_{2} \mathrm{CO}_{3}$ $0,75 \%$. Untuk lebih jelasnya dapat dilihat pada Gambar 3. Hasil uji statistik menunjukkan bahwa kombinasi perlakuan konsentarsi larutan $\mathrm{KOH}$, lama waktu perendaman dalam larutan $\mathrm{KOH}$ yang kemudian diekstrak menggunakan larutan $\mathrm{Na}_{2} \mathrm{CO}_{3}$ pada berbagai konsentrasi menunjukkan pengaruh nyata

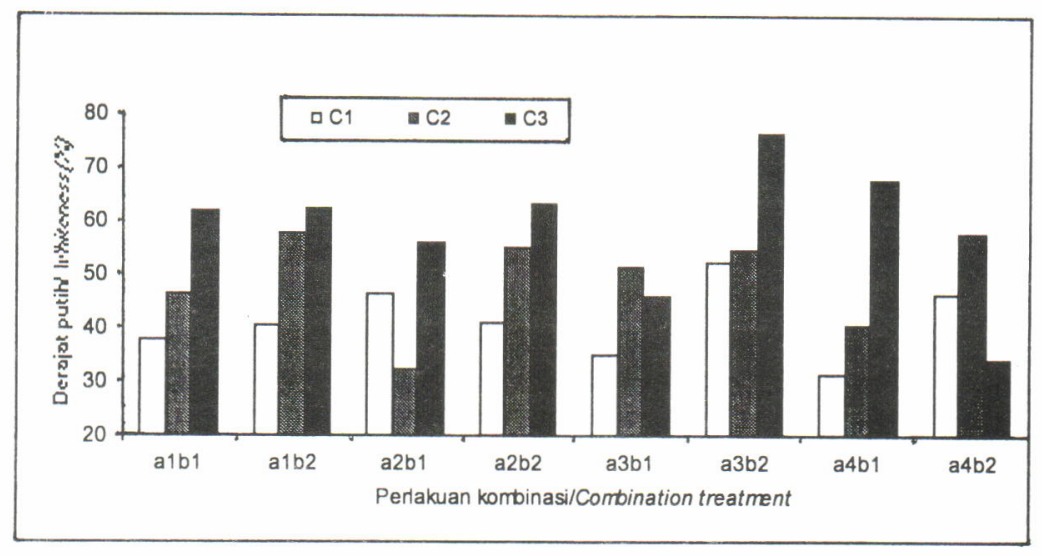

Gambar 3. Nilai derajat putih Na-alginat.

Figure 3. Whiteness value of Na-alginate.

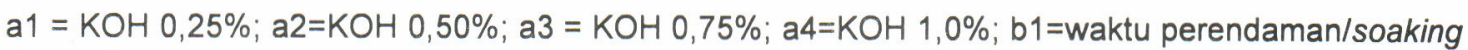
time $=30$ menit $(\mathrm{min}) ; \mathrm{b} 2=$ waktu perendaman/soaking time $=60$ menit $(\mathrm{min}) ; \quad \mathrm{c} 1=\mathrm{Na}_{2} \mathrm{CO}_{3} \quad 0,75 \%$; $\mathrm{c} 2=\mathrm{Na}_{2} \mathrm{CO}_{3} 1,50 \% ; \mathrm{c} 3=\mathrm{Na}_{2} \mathrm{CO}_{3}$. 
terhadap nilai derajat putih dengan tingkat kepercayaan 95\%. Sedangkan interaksi antara perlakuan konsentrasi larutan $\mathrm{KOH}$ dengan lama perendaman 30 dan 60 menit, antara perlakuan konsentrasi larutan $\mathrm{KOH}$ dengan perlakuan konsentrasi $\mathrm{Na}_{2} \mathrm{CO}_{3}$, serta antara lama perendaman dengan perlakuan konsentrasi $\mathrm{Na}_{2} \mathrm{CO}_{3}$ juga menunjukkan pengaruh yang nyata terhadap derajat putih natrium aiginat yang dihasilkan. Untuk melihat masing-masing faktor yang diperlakukan memberikan hasil terbaik telah diuji menggunakan perbandingan wilayah berganda Duncan. Hasil analisis menunjukkan bahwa perlakuan larutan KOHi $0,75 \%$ memberikan nilai derajat putih tertinggi dibandingkan konsentrasi larutan $\mathrm{KOH}$ yang lainnya $(0,25 \%$, $0,50 \%$, dan $1,0 \%$ ) dan saling berpengaruh nyata satu dengan yang lainnya. Lama perendaman antara 30 menit dan 60 menit juga berpengaruh nyata. Sedangkan untuk perlakuan konsentrasi $\mathrm{Na}_{2} \mathrm{CO}_{3}$ menunjukkan bahwa masing-masing konsentrasi memberikan perbedaan yang nyata terhadap nilai derajat putih yang dihasilkan.

Interaksi antara perlakuan perendaman dalam larutan $\mathrm{KOH}$ dengan lama waktu perendaman memperlihatkan bahwa rumput laut yang direndam larutan $\mathrm{KOH} \quad 0,75 \%$ selama 60 menit memberikan nilai derajat putih tertinggi dan berbeda nyata dengan rumput laut yang direndam dalam larutan

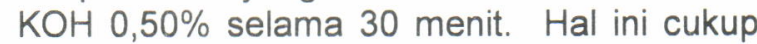
beralasan karena semakin lama perendaman dan semakin tinggi larutan alkali yang digunakan akan memungkinkan sejumlah pigmen santofil (violasantin, fukosantin, flavosantin, neosantin a dan b) serta pigmen klorofil a dan c terlarut dalam larutan alkali (Smith, 1955). Peningkatan konsentrasi $\mathrm{KOH}$ yang diikuti dengan lamanya waktu perendaman rumput laut cenderung meningkatkan nilai derajat putih. Akan tetapi bila konsentrasi $\mathrm{KOH}$ ditingkatkan hingga $1,0 \%$ nilai derajat putih cenderung menurun. Terjadinya penurunan nilai derajat putih pada perlakuan larutan $\mathrm{KOH} 1,0 \%$ yang direndam selama 60 menit diperkirakan karena fukosantin yang ada di dalam rumput laut masih banyak yang tertinggal. Tseng (1946) menyatakan bahwa fungsi utama larutan alkali pada perendaman rumput laut adalah untuk deproteinasi dan bukan untuk menarik zat warna. Penarikan protein dari rumput laut akan semakin cepat bila konsentrasi larutan alkali yang diberikan semakin tinggi sehingga tidak memungkinkan penarikan zat warna bersama-sama dengan protein keluar dari jaringan sel rumput laut.

Interaksi perlakuan perendaman larutan $\mathrm{KOH}$ dengan perlakuan larutan pengekstraksi $\left(\mathrm{Na}_{2} \mathrm{CO}_{3}\right)$ memberikan perbedaan yang nyata terhadap derajat putih. Nilai rata-rata tertinggi derajat putih ditemukan pada perlakuan perendaman rumput laut di dalam larutan $\mathrm{KOH} \mathrm{0,25 \%} \mathrm{yang} \mathrm{diekstrak} \mathrm{dengan} \mathrm{larutan}$ $\mathrm{Na}_{2} \mathrm{CO}_{3} .2,25 \%$. Pada perlakuan ekstraksi $\mathrm{Na}$-alginat menggunakan larutan $\mathrm{Na}_{2} \mathrm{CO}_{3}$ pada konsentrasi lebih kecil dari $2,25 \%$ cenderung menurunkan nilai derajat putih. Dengan demikian terbukti bahwa penggunaan konsentrasi $\mathrm{KOH}$ yang berlebihan akan menurunkan nilai derajat putih $\mathrm{Na}$-alginat yang dihasilkan. Pada penelitian ini konsentrasi larutan $\mathrm{KOH}$ yang diberikan hingga $1,0 \%$ belum mampu menarik pigmen fukosantin keluar dari Na-alginat secara maksimal.

\section{Susut Pengeringan}

Susut pengeringan (anhydrous clean seaweed) adalah salah satu kriteria dalam menentukan tingkat kebersihan rumput laut setelah panen. Diketahui bahwa pada permukaan thallus rumput laut selama masa pertumbuhan akan ditutupi oleh kotoran (seperti lumut, lumpur, dan garam) sehingga sebelum dilakukan proses ekstraksi harus dibersihkan. Adanya perlakuan perendaman di dalam larutan $\mathrm{KOH}$ dimaksudkan disamping untuk mereduksi kotoran di permukaan thallus, juga untuk mempertahankan kandungan alginat di dalam thallus. Kadar kotor tidak hanya dapat dihilangkan dengan perlakuan asam tetapi dapat juga dihilangkan dengan perlakuan basa/alkali. Hasil penelitian penggunaan larutan alkali $(\mathrm{KOH})$ terhadap kadar susut pengeringan berkisar antara $18,4 \%-21,71 \%$. Nilai susut pengeringan tertinggi diperoleh dari kombinasi perlakuan perendaman rumput laut di dalam larutan $\mathrm{KOH} 0,75 \%$ selama 60 menit yang kemudian diekstrak dengan larutan $\mathrm{Na}_{2} \mathrm{CO}_{3} \quad 0,75 \%$. Pada Gambar 4 dapat dilihat nilai susut pengeringan $\mathrm{Na}$-alginat.

Hasil uji statistik menunjukkan bahwa perlakuan kombinasi perendaman dengan larutan $\mathrm{KOH}$ dan diekstrak dengan larutan $\mathrm{Na}_{2} \mathrm{CO}_{3}$ serta interaksi semua faktor perlakuan berpengaruh nyata terhadap kadar susut pengeringan pada tingkat kepercayaan $95 \%$. Untuk melihat pengaruh nyata antara 


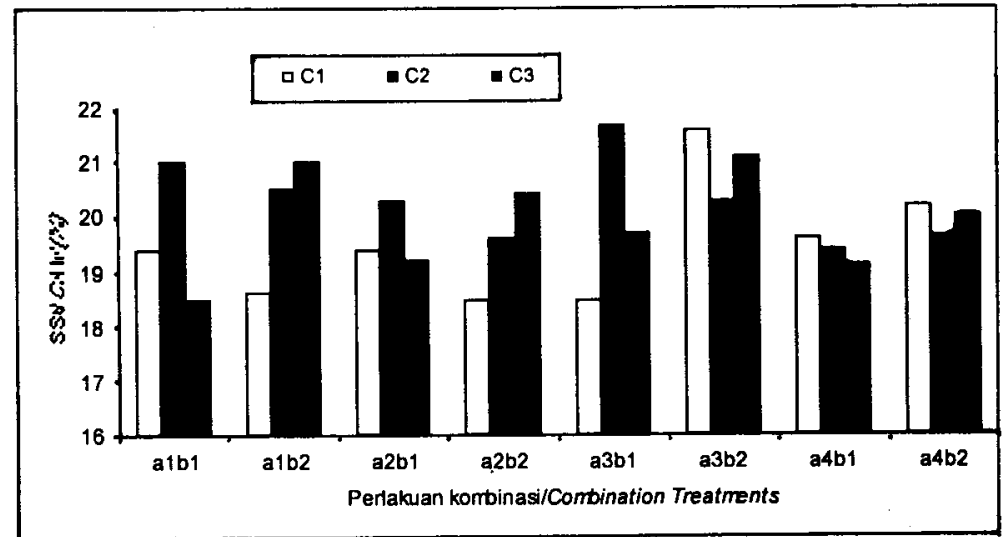

Gambar 4. Nilai susut pengeringan Na-alginat setelah mendapatkan perlakuan Figure 4. Clean anhydrous seaweed value of $\mathrm{Na}$-alginate after treatments

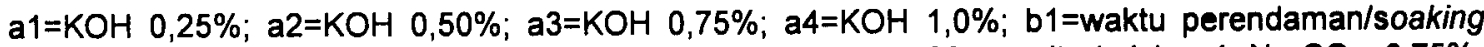
time $=30$ menit $(\mathrm{min}) ; \mathrm{b} 2=$ waktu perendaman/soaking time $=60$ menit $(\mathrm{min}) ; \quad \mathrm{c} 1=\mathrm{Na}_{2} \mathrm{CO}_{3} \quad 0,75 \%$; $\mathrm{c} 2=\mathrm{Na}_{2} \mathrm{CO}_{3} 1,50 \% ; \mathrm{c} 3=\mathrm{Na}_{2} \mathrm{CO}_{3} 2,25 \%$.

satu faktor dengan yang lain maka pengujian statistik dilanjutkan menggunakan uji perbandingan wilayah berganda Duncan. Ternyata perlakuan larutan $\mathrm{KOH} 0,75 \%$ berpengaruh nyata terhadap larutan $\mathrm{KOH}$ $0,25 \%, 0,50 \%$ dan $1,0 \%$. Sedangkan antara larutan $\mathrm{KOH} \quad 0,25 \%, 0,50 \%$ dan $1,0 \%$, masing-masing tidak menunjukkan perbedaan yang nyata. Lama waktu perendaman 60 menit juga berpengaruh nyata dengan lama waktu perendaman 30 menit begitu pula masing-masing konsentrasi larutan $\mathrm{Na}_{2} \mathrm{CO}_{3}$ $(0,75 \%, \quad 1,50 \%$ dan $2,25 \%)$ berpengaruh nyata satu dengan yang lainnya.

Interaksi antara perlakuan konsentrasi $\mathrm{KOH}$ dengan lama perendaman dari hasil pengujian wilayah berganda Duncan menunjukkan bahwa nilai susut pengeringan yang terbaik ditemukan pada perlakuan perendaman larutan $\mathrm{KOH} 0,75 \%$ selama 60 menit. Interaksi perlakuan perendaman dalam larutan $\mathrm{KOH}$ dengan ekstraksi menggunakan $\mathrm{Na}_{2} \mathrm{CO}_{3}$ menunjukkan bahwa perlakuan larutan $\mathrm{KOH} 0,75 \%$ yang diekstrak dengan larutan $\mathrm{Na}_{2} \mathrm{CO}_{3} \quad 1,50 \%$ hanya berpengaruh nyata terhadap perlakuan larutan $\mathrm{KOH} 1,0 \%$ yang diekstrak dengan larutan $\mathrm{Na}_{2} \mathrm{CO}_{3}(2,25 \%$ dan $1,50 \%$ ), perlakuan larutan $\mathrm{KOH} 0,25 \%$ yang diekstrak dengan larutan $\mathrm{Na}_{2} \mathrm{CO}_{3} 0.75 \%$, dan perlakuan larutan $\mathrm{KOH} \quad 0,50 \%$ yang diekstrak dengan larutan $\mathrm{Na}_{2} \mathrm{CO}_{3} \quad 0.75 \%$. Sedangkan interaksi antara lama perendaman dengan konsentrasi larutan pengekstrak $\mathrm{Na}_{2} \mathrm{CO}_{3}$ menunjukkan perlakuan lama perendaman 60 menit yang diekstrak dengan larutan $\mathrm{Na}_{2} \mathrm{CO}_{3} 2,25 \%$ berpengaruh nyata terhadap perlakuan lama perendaman 30 menit yang diekstrak dengan larutan $\mathrm{Na}_{2} \mathrm{CO}_{3}$ $0,75 \%$ dan perlakuan lama perendaman 30 menit yang diekstrak dengan larutan $\mathrm{Na}_{2} \mathrm{CO}_{3}$ $2,25 \%$.

Interaksi perlakuan perendaman larutan $\mathrm{KOH}$ dengan waktu perendaman, perlakuan perendaman larutan $\mathrm{KOH}$ dengan larutan pengekstrak $\left(\mathrm{Na}_{2} \mathrm{CO}_{3}\right)$ serta interaksinya dengan waktu perendaman ditemukan bahwa nilai susut pengeringan tertinggi pada perlakuan perendaman rumput laut menggunakan larutan $\mathrm{KOH} 0,75 \%$ baik untuk rumput laut yang direndam selama 30 menit maupun 60 menit. Pada perlakuan perendaman dalam larutan $\mathrm{KOH}$ lebih kecil atau lebih besar dari pada $0,75 \%$, menurunkan nilai kadar susut pengeringan. Keadaan ini juga didukung oleh interaksi antara perlakuan perendaman dalam larutan $\mathrm{KOH}$ dengan perlakuan ekstraksi menggunakan larutan $\mathrm{Na}_{2} \mathrm{CO}_{3}$. Peningkatan konsentrasi larutan $\mathrm{KOH}$ hingga $0,75 \%$ yang kemudian diekstrak alginatnya menggunakan berbagai konsentrasi $\mathrm{Na}_{2} \mathrm{CO}_{3}$ cenderung meningkatkan nilai susut pengeringan. Menurut Yani (1988) kadar susut pengeringan tidak hanya dipengaruhi oleh proses isolasi natrium alginat tetapi juga dipengaruhi oleh kadar air rumput laut selama penyimpanan.

\section{KESIMPULAN}

Hasil penelitian menunjukkan bahwa perendaman dalam larutan $\mathrm{KOH}$ pada berbagai konsentrasi tidak berpengaruh nyata terhadap rendemen $\mathrm{Na}$-alginat, namun demikian berpengaruh nyata terhadap tingkat 
kekentalan, derajat putih, dan kadar susut pengeringan. Sedangkan lama perendaman dan konsentrasi larutan $\mathrm{Na}_{2} \mathrm{CO}_{3}$ sebagai bahan kimia pengekstrak alginat berpengaruh nyata terhadap rendemen, tingkat kekentalan, derajat putih dan kadar susut pengeringan. Berdasarkan parameter tingkat kekentalan maka perlakuan perendaman dalam larutan $\mathrm{KOH} 0,50 \%$ selama 60 menit yang kemudian diekstrak dengan larutan $\mathrm{Na}_{2} \mathrm{CO}_{3} \quad 1,50 \%$ merupakan kombinasi perlakuan yang terbaik.

Untuk meningkatkan nilai derajat putih $\mathrm{Na}$ alginat yang diperoleh dari rumput laut coklat perlu diteliti lebih lanjut terutama jenis dan konsentrasi bahan bleaching agent.

\section{DAFTAR PUSTAKA}

Anonimus. 2000. Laporan Hasil Penelitian Tahun Anggaran, 1998/1999. Instalasi Penelitian Perikanan Laut Slipi . 108 p.

Basmal, J., Tampubolon, M. dan Marsina, E. 1991. Effect of $\mathrm{KOH}$ concentration of alkali treatment on quality of Semi refined carrageenan. Jurnal Penelitian Pasca Panen Perikanan (74):1- 8

Basmal, J., Yunizal, dan Murtini, J.T. 1998a Pengaruh volume dan waktu ekstraksi natrium alginat dalam larutan natrium karbonat. Makalah disajikan dalam Forum Komunikasi I. Ikatan Fikologi Indonesia. Serpong, 8 September 1999. p. 119-126.

..---.-., Yunizal, dan Tazwir. 1998b. Pengaruh perlakuan pembuatan semi refined alginat dari rumput laut coklat (Turbinaria ornata) segar terhadap kualitas sodium alginat. Makalah disajikan dalam Forum Komunikasi l. Ikatan Fikologi Indonesia. Serpong, 8 September 1999. p. $97-110$ 2002. Kajian Sifat-Sifat Fisika Rumput Laut Penghasil Alginat. Belum diterbitkan.

Chapman, V.J. and Chapman, D.J. 1980. Seaweed And Their Uses. $3^{\text {rd }}$ Edition. Chapman and Hall, New York. 334 p.
Cottrel dan Kovacs, P. 1980. Alginates. In Davidson, R.L. (ed). Hand Book of Water Soluble Gums and Resin. McGraw-Hill Book Co, New York. p. 2-43.

Istini, S. dan Zatnika, A.1991. Optimalisasi proses semirefine carrageenan dari rumput laut Euchema cottonii. Prosiding Temu Karya IImiah Teknologi Pasca Panen Rumput Laut, Jakarta, 11-12 Maret 1991. Sub Balai Penelitian Perikanan Laut Slipi, Departemen Pertanian. p. 87-100.

King, H.K. 1983. Brown seaweed extract (Alginates) In Glicksman M. (ed). Food Hydrocolloids. Volume II. CRC Press, Inc. Boca Raton, Florida, p. 115-182.

McHugh, D.J. 1987. Production, properties and uses of alginates. In McHugh, D.J. (ed). Production and Utilization of Product from Commercial Seaweed. FAO. Fisheries Technical Paper, Rome. p. 58-131.

Percival, E. 1970. Algae polysaccarides. In Pigman, W. dan Horton, D. (eds). The Carbohydrates Chemistry and Biochemistry. 2nd. Academic Press, New York. $285 \mathrm{p}$.

Smith, G.M. 1955. Cryptogamic Botany. $2^{\text {nd }}$ Ed. Volume I.McGraw-Hill Book Inc. New York.217p.

Sudjana, M.A. 1988. Desain and Analisis Eksperimen. Edisi III. Tarsito, Bandung. 272 p.

Tseng, O.K. 1946. Phycocolloids useful seaweed polysaccharides. In Alexander (Ed). Collopids Chemistry Theoretical and Applied. Volume VI. Reinhold Publishing Corporation, New York. p. 629-734

Yani, M. 1988. Modifikasi dan Optimalisasi Proses Ekstraksi dalam Rancang Bangun Proses Tepung Algin dari Jenis Turbinaria Ornata. Skripsi. Fakultas Teknologi Pertanian, IPB, Bogor. $130 \mathrm{p}$.

Walpole, R.E. 1995. Pengantar Statistik. PT. Gramedia Pustaka Utama, Jakarta. 183 p.

Winarno, F.G. 1990. Teknologi Pengolahan Rumput Laut. Pustaka Sinar Harapan, Jakarta. $86 \mathrm{p}$. 